\title{
VULNERABILITY TO COASTAL FLOODING INDUCED BY TROPICAL CYCLONES
}

\author{
Gregorio Posada-Vanegas ${ }^{1}$, Gerardo Durán-Valdez ${ }^{2}$,Rodolfo Silva-Casarín ${ }^{3}$. María Elena Maya Magaña ${ }^{4}$, \\ José Antonio Salinas-Prieto ${ }^{5}$
}

\begin{abstract}
Hurricanes are a recurrent feature on Mexican coasts; the floods they create often cause great economic and social damage. The evaluation of the natural hazards related to storm surge is fundamental in reducing risks for the populations of coastal areas. In order to generate flood hazard maps, storm surge associated with different return periods is computed with a 2D numerical model. The first part of this work explains the data and numerical models used to calculate the storm surge, the second part contains the results obtained with the simulations. This work has been done for the entire Mexican coastline.
\end{abstract}

Keywords: hurricanes; numerical model; storm surge

\section{INTRODUCTION}

This paper presents a methodology developed for computing the storm surge levels for different return periods associated with hurricanes on Mexican coasts. It is based on two numerical models (HURAC and HD23) developed by the Engineering Institute of the UNAM and the Center EPOMEXUAC. The results presented are for the Gulf of Mexico and the North Pacific area of Mexico.

\section{METHODOLOGY}

\section{Bathymetry}

Getting the bathymetry is always a task in itself in Latin-American countries; this stage was achieved through a digitalization process using navigation and bathymetry charts belonging to the Mexican Navy. Figure 1 shows the final bathymetry used to evaluate the storm surge levels on the Gulf of México.

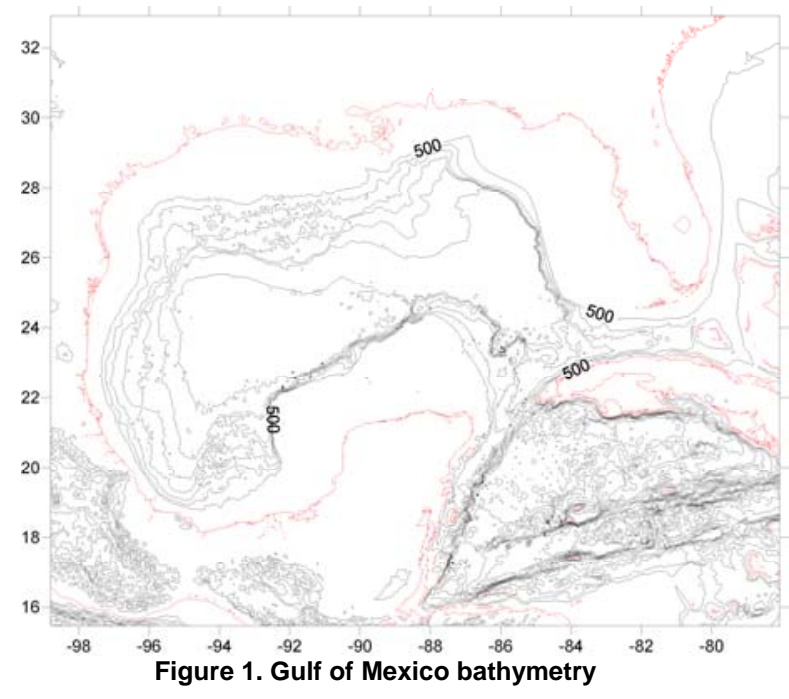

${ }^{1}$ Centro EPOMEX, Universidad Autónoma de Campeche, Av. Agustín Melgar S/N entre Juan de la Barrera y Calle 20, San Francisco de Campeche, Campeche, 24039, México, gposadav@uacam.mx, corresponding author

${ }^{2}$ Grupo de Ingeniería de Costas y Puertos, Coordinación de Hidráulica, Instituto de Ingeniería, Universidad Nacional Autónoma de México, Ciudad Universitaria, Instituto de Ingeniería, Edificio 5, Cub 404. México D.F, 04510, gduranv@iingen.unam.mx

3 Grupo de Ingeniería de Costas y Puertos, Coordinación de Hidráulica, Instituto de Ingeniería, Universidad Nacional Autónoma de México, Ciudad Universitaria, Instituto de Ingeniería, Edificio 5, Cub 406. México D.F, 04510, rsilvac@iingen.unam.mx

4 Instituto Mexicano de Tecnología del Agua, Paseo Cuahnáhuac \# 8532, Colonia Progreso, Jiutepec, Morelos, 62550, emayamg@yahoo.com.mx

5 Instituto Mexicano de Tecnología del Agua, Paseo Cuahnáhuac \# 8532, Colonia Progreso, Jiutepec, Morelos, 6255, isalinas@imta.gob.mx 


\section{HURAC Model}

The next step was to use the database, with main hurricane parameters, which had been previously gathered by the Engineering Institute of the National University of Mexico, from meteorological reports published by NOAA for the years $1949-2008$. Figure 2 indicates all the cyclones which crossed Mexican seas in this period. For the Atlantic basin there is a total of 659 cyclones, for the Pacific the data base contains 860. The hurricanes considered relevant were those which had passed closer than $200 \mathrm{~km}$ from the coasts of the states that are part of Gulf of Mexico (Yucatán, Campeche, Tabasco, Veracruz and Tamaulipas) and the Mexican Pacific (Chiapas, Oaxaca, Guerrero, Colima, Jalisco, Nayarit, Sinaloa, Sonora, Baja California Sur and Baja California).

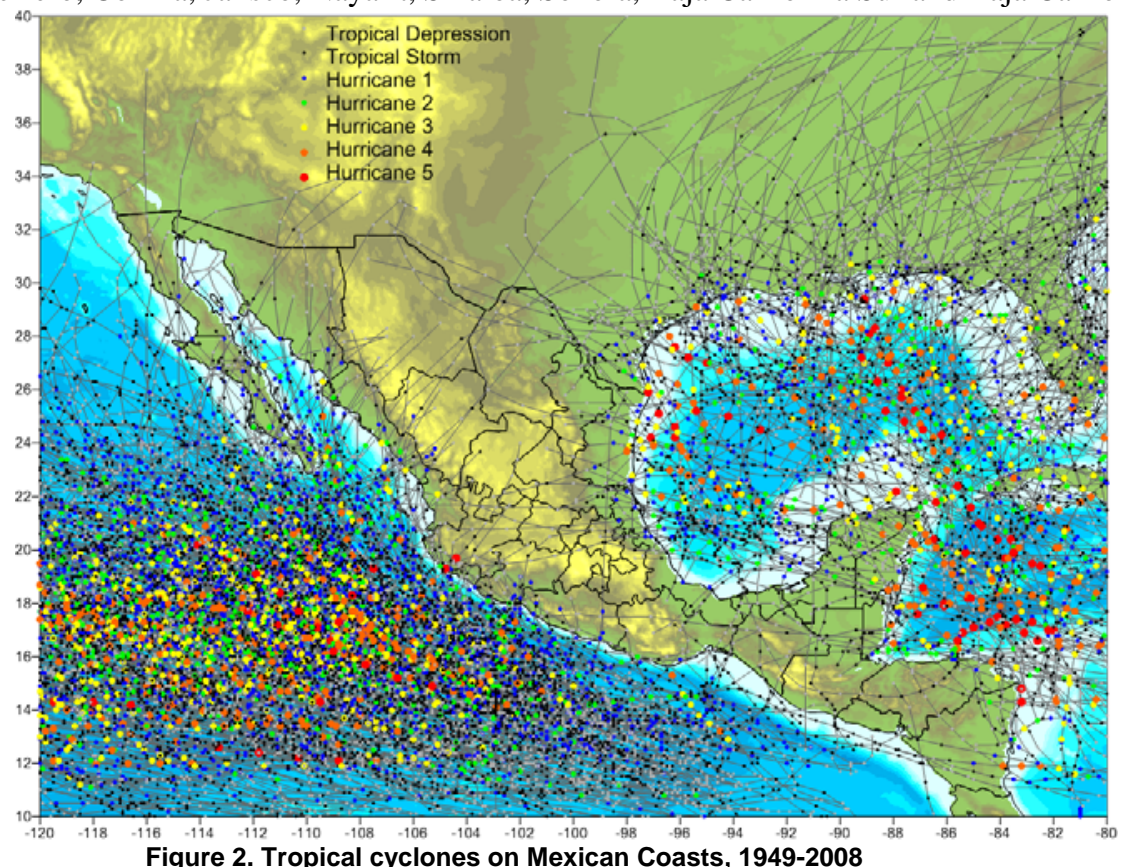

From this information, the parametric cyclone model, HURAC, developed by Ruiz et al (2009) was executed. This model estimates the wind, wave and pressure fields knowing the position and cyclostrophic radius of the hurricane, and is based on the work presented by Bretschneider, 1990 and modified by Silva, 2000. The atmospheric field pressure is calculated with equation (1) and the wind module solves the equation (2)

$$
\begin{gathered}
P_{r}=P_{0}+\left(P_{N}-P_{0}\right) e^{\left(-\frac{R}{r}\right)} \\
W=0.886\left[F_{V} U_{R}+0.5 V_{F} \cos (\theta+\beta)\right] \\
U_{R}=21.8\left(P_{N}-P_{0}\right)^{1 / 2}-0.5 f R \\
f=2 \omega \sin \phi \\
\omega \approx 0.2618 \frac{\mathrm{rad}}{h}
\end{gathered}
$$

Figure 3a presents the atmospheric pressure variations for Cozumel Island, calculated with the pressure module and measured at one of the meteorological stations of the Mexican Meteorological System (SMN). For Hurricane Wilma, 2005, the good agreement between the two graphs can been observed. Figure $3 \mathrm{~b}$ represents the calculated wind velocity module and that measured by a NOAA buoy for the same hurricane. Illustrations 5 and 6 represent the pressure and velocities fields calculated with HURAC for Hurricane Emily, 2005. 


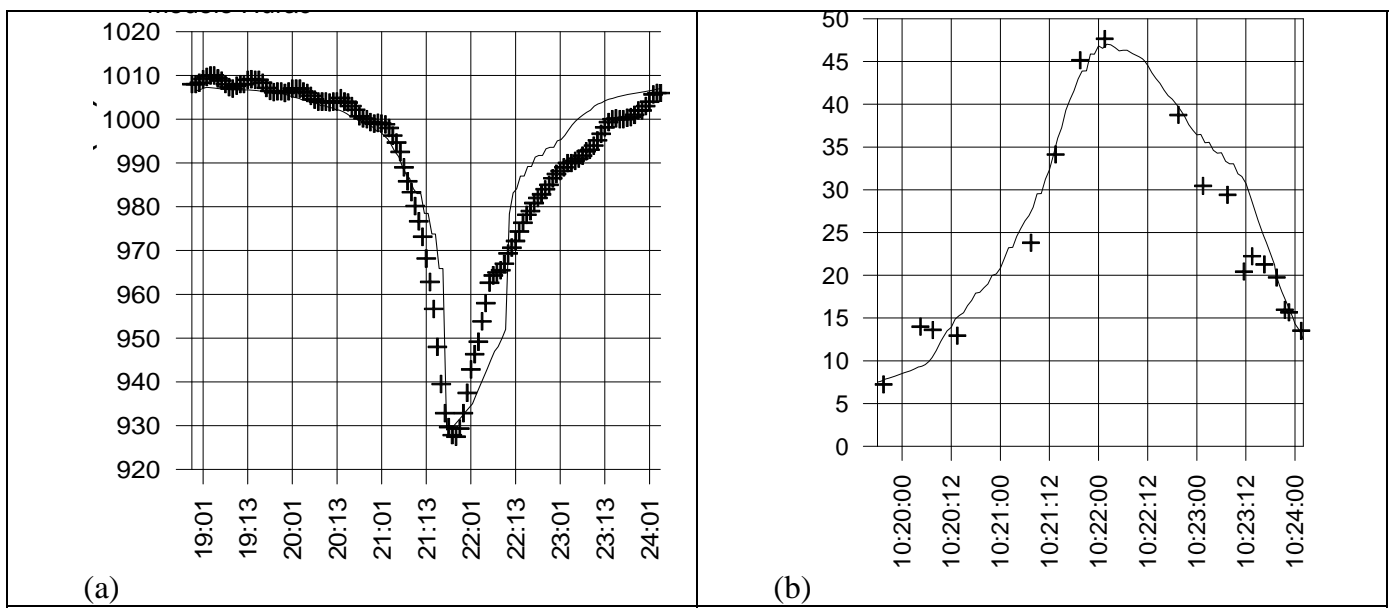

Figure 3. Pressure and wind velocity variations calculated and measured for hurricane Wilma, 2005

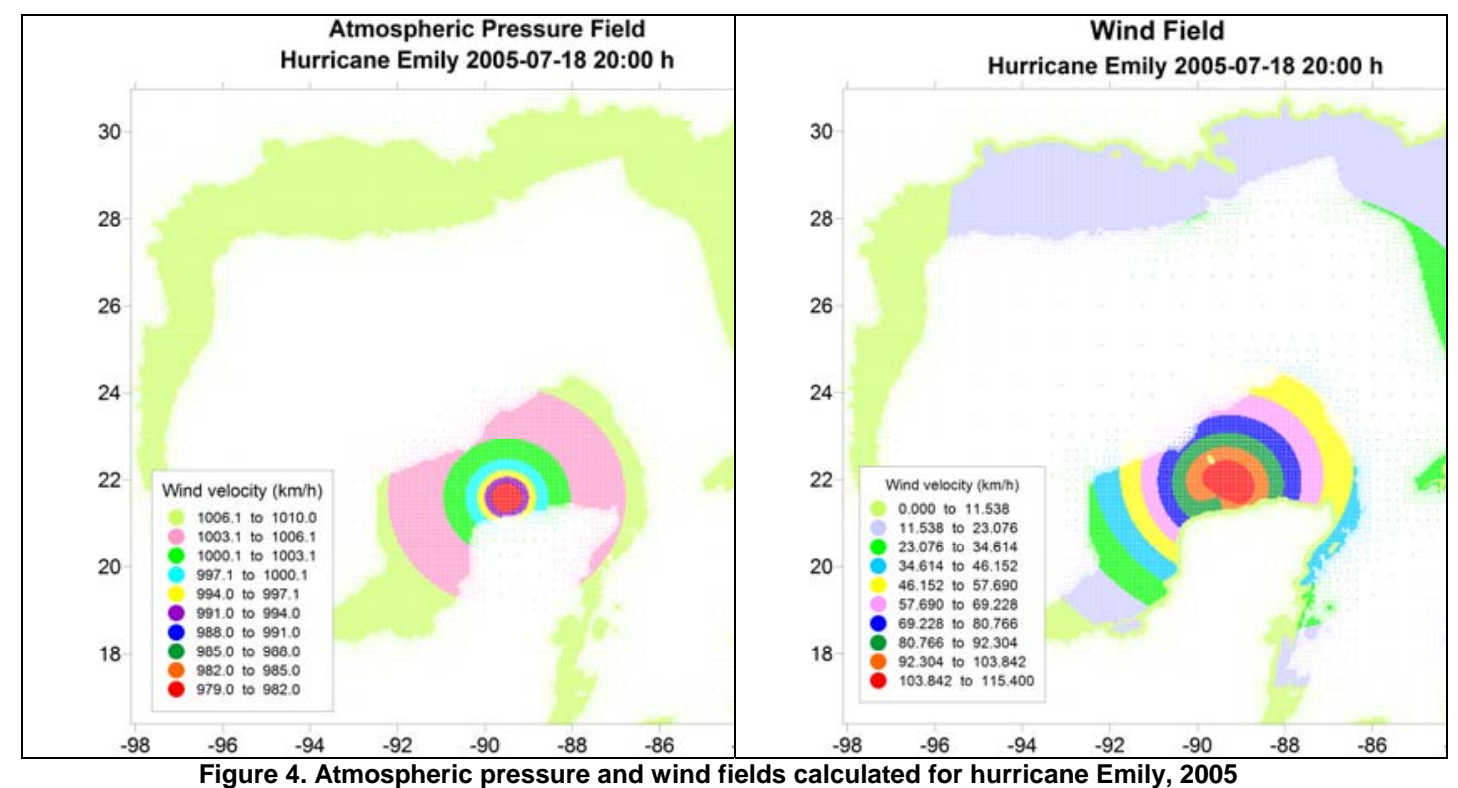

\section{Numerical model, HD23}

From the pressure and wind fields the storm surge level is calculated with a model developed by Posada et al (2008). This numerical model solves the governing equations with a finite volume scheme in two dimensions, based on a Gudonov scheme, using the hierarchical mesh. To resolve in-viscid flows we employ a Riemman solver to calculate the approximation proposed by Roe, in a similar way to Bautista, 2005. The time integration is carried out with a first-order Adams-Bashforth scheme.

The depth-averaged equations, solved by the model in 2 dimensions are:

\section{Continuity Equation}

$$
\frac{\partial(U H)}{\partial x}+\frac{\partial(V H)}{\partial y}+\frac{\partial H}{\partial t}=0
$$

Where $H=h+\eta$

$\eta$ = free surface elevation with respect to the bottom.

$\mathrm{h}=$ the bottom depth with respect to the mean water level. 
Momentum equation in $\mathrm{X}$-direction

$$
\begin{aligned}
& \frac{\partial(U H)}{\partial t}+\frac{\partial U^{2} H}{\partial x}+\frac{\partial}{\partial x} \int_{-h}^{\eta}\left(u^{\prime}\right)^{2} d z+\frac{\partial U V H}{\partial y}+\frac{\partial}{\partial y} \int_{-h}^{\eta} u^{\prime} v^{\prime} d z= \\
& f V H-g H \frac{\partial \eta}{\partial x}+\frac{1}{\rho_{o}}\left(\tau_{x z(\eta)}-\tau_{x z(-h)}\right)+H \varepsilon_{h}\left(\frac{\partial^{2} U}{\partial x^{2}}+\frac{\partial^{2} U}{\partial y^{2}}\right)+ \\
& 2 H \frac{\partial U}{\partial x} \frac{\partial \varepsilon_{h}}{\partial x}+H \frac{\partial \varepsilon_{h}}{\partial y}\left(\frac{\partial U}{\partial y}+\frac{\partial V}{\partial x}\right)
\end{aligned}
$$

Where:

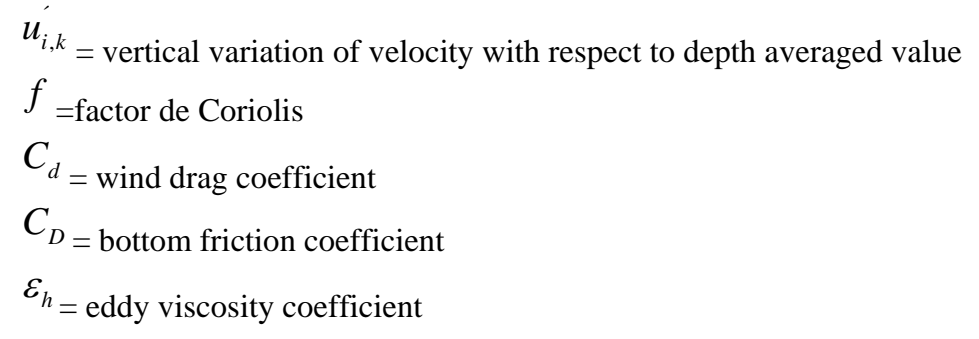

\section{Momentum equation in Y-direction}

$$
\begin{aligned}
& \frac{\partial(V H)}{\partial t}+\frac{\partial U V H}{\partial x}+\frac{\partial}{\partial x} \int_{-h}^{\eta} u^{\prime} v^{\prime} d z+\frac{\partial V^{2} H}{\partial y}+\frac{\partial}{\partial y} \int_{-h}^{\eta}\left(v^{\prime}\right)^{2} d z= \\
& -f U H-g H \frac{\partial \eta}{\partial y}+\frac{1}{\rho_{o}}\left(\tau_{y z(\eta)}-\tau_{y z(-h)}\right)+H \varepsilon_{h}\left(\frac{\partial^{2} V}{\partial x^{2}}+\frac{\partial^{2} V}{\partial y^{2}}\right)+ \\
& 2 H \frac{\partial V}{\partial y} \frac{\partial \varepsilon_{h}}{\partial y}+H \frac{\partial \varepsilon_{h}}{\partial x}\left(\frac{\partial U}{\partial y}+\frac{\partial V}{\partial x}\right)
\end{aligned}
$$

\section{Momentum equation in Y-Boundary Condition 2D Model}

The boundary conditions employed by the model are as follows:

\section{Closed boundaries}

At closed boundaries, the normal component of the velocity is set at zero whilst a slip condition preserves the tangential velocity.

Open Boundaries: lateral

In the case of open borders two boundary conditions are considered. First, for the free surface and the parallel components of velocity, the boundary is totally absorbing so that these boundary values are set equal to zero. Secondly, for the perpendicular velocity components, the border is totally transmissive, thus these components are unaffected across the boundary.

Open boundary: upper

The shear stress due to the wind is of the form

$$
\tau_{x z(\eta)}=C_{a} \rho_{a} W_{x} W
$$

Where Ca is the drag coefficient of the wind, which has a value of 0.0026, Falconer, 1994. The shear stress due to friction at the sea bed is calculated with the expression 


$$
\tau_{x z(-h)}=\rho_{o} C_{D}|\bar{v}| u_{-h}
$$

where $C_{a}$ it is the friction coefficient, which is a function of the Chezy coefficient

\section{Eddy Viscosity coefficient in 2D}

The numerical model provides two options. The first is to consider this coefficient as a constant. The second is to consider the viscosity coefficient as a variable, calculated with the following expression.

$$
\varepsilon_{h}=l^{2}\left[\left(\frac{\partial U}{\partial x}\right)^{2}+\left(\frac{\partial V}{\partial y}\right)^{2}+\frac{1}{2}\left(\frac{\partial U}{\partial y}+\frac{\partial V}{\partial x}\right)^{2}\right]^{1 / 2}
$$

Where: $l^{2}=0.1 \Delta x \Delta y$ according to Castanedo 2000 .

\section{Quadtree mesh}

The numerical model described in the last section works on a quadtree mesh. The advantages and the means of generating this kind of mesh is described in detail in Posada et al 2008. The quadtree mesh is easily generated and resolution is good for the area of interest. In figure 5, the numerical mesh for the Gulf of Mexico is presented; note the high resolution for the cells on the coastline (3,150 m) in contrast to the coarser resolution for the center of the Gulf $(101,000 \mathrm{~m})$. In this mesh the total number of cells is 79,537, covering an area of 2'560.000 $\mathrm{km}^{2}$ The Mexican Pacific littoral was divided in two areas, one for the north-west part (Baja California, Baja California Sur, Sonora, Sinaloa states) the other one for South-east part that include the states of Nayarit, Jalisco, Colima, Michoacán, Guerrero, Oaxaca and Chiapas). Figure 6 shows the mesh for the North Pacific area, in which the minimum cell size is 3,900 $\mathrm{m}$ and the large cells $120,000 \mathrm{~m}$. This mesh has 44,227 cells.

\section{STORM SURGE LEVELS}

The hurricane analysis consisted in the modeling of all the hurricanes for each year, between 1949 and 2009, which had passed closer than $200 \mathrm{~km}$ to the Mexican coast, obtaining the maximum yearly storm surge. Where a year has 2 or more such hurricanes all of them were modeled, and the maximum storm surge level for a specified cell is the maximum level of all the simulations for this year. Later, extreme analyses were made, applying the Weibull distribution to the maximum levels for each of the cells that are part of a state region. With this statistical analysis it was possible to obtain flood hazard forecasts for hurricanes for each Mexican coastal state with return periods from 5-1000 years.

Figures 7a,b and c represent the maximums storm surge levels reached in Campeche State for hurricanes Emily, Stan and Wilma in 2005. Figure 7d, represents the maximum level for each cell based on the calculated maximums levels.

Figure 8, shows the Weibull distribution for maximum levels for different return periods for San Francisco de Campeche, Campeche, a city located in the western part of the Yucatan Peninsula. This kind of graph was obtained for all the coastal cells of the littoral.

\section{RESULTS}

Figure 9 shows the time evolution of the pressure and storm surge associated with hurricane Gilbert, a tropical cyclone that caused tremendous damage in Mexico, in 1998, principally in the states of Quintana Roo, Tamaulipas and, associated with rain, in the inland state of Nuevo Leon. The maximum storm surge level modeled was in the Yucatan Peninsula and had a value of almost $4.0 \mathrm{~m}$. 

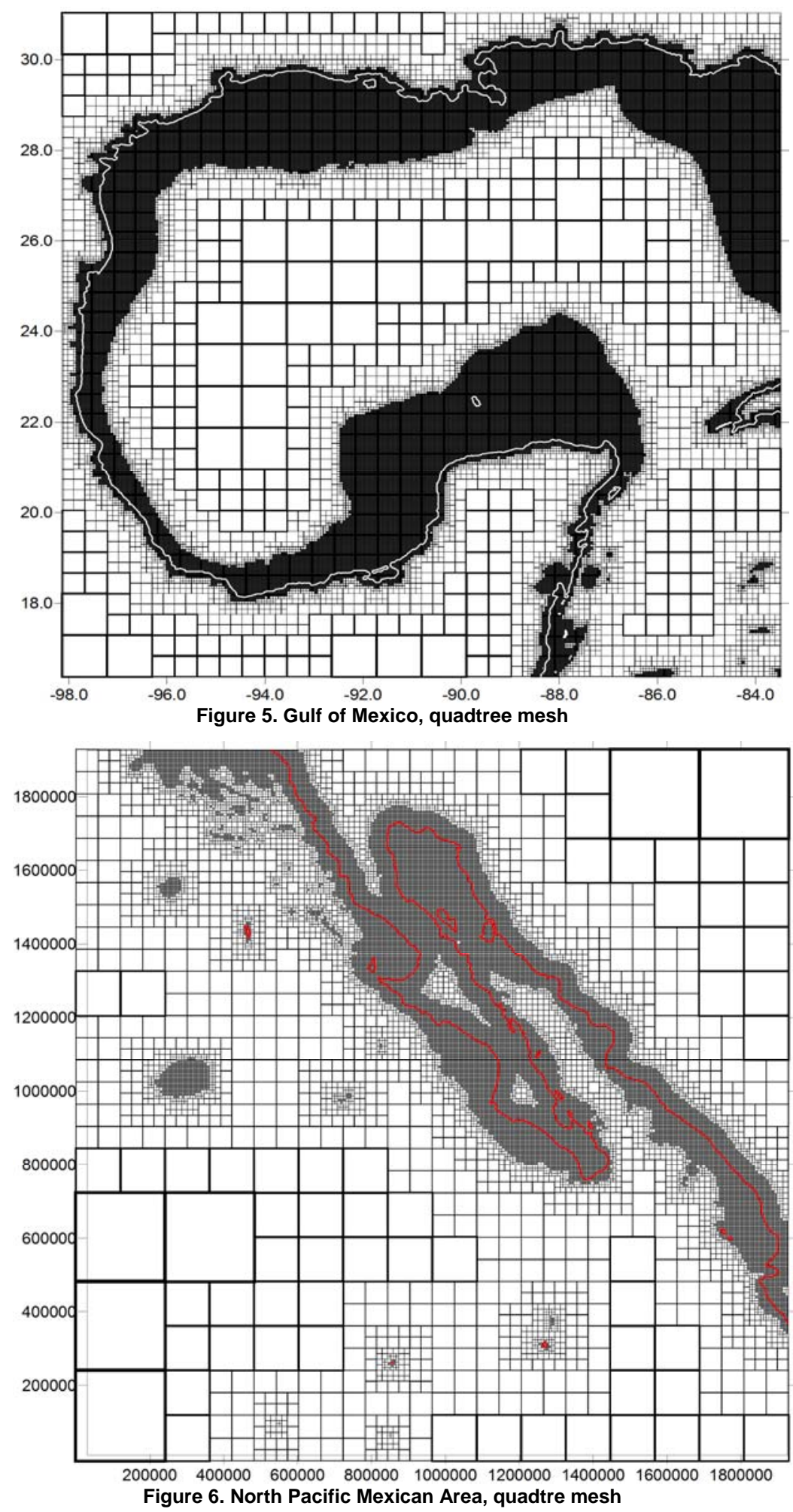


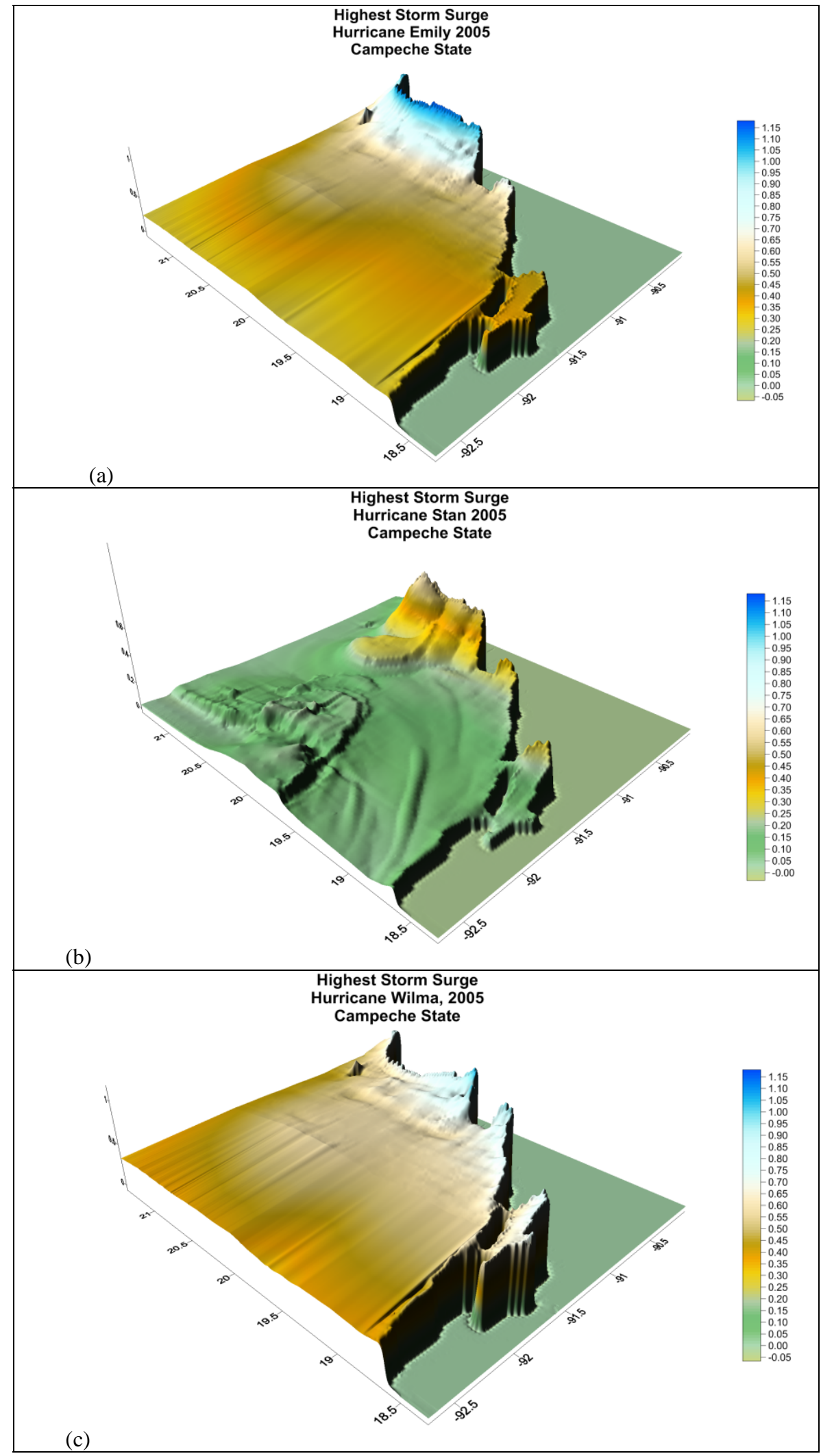




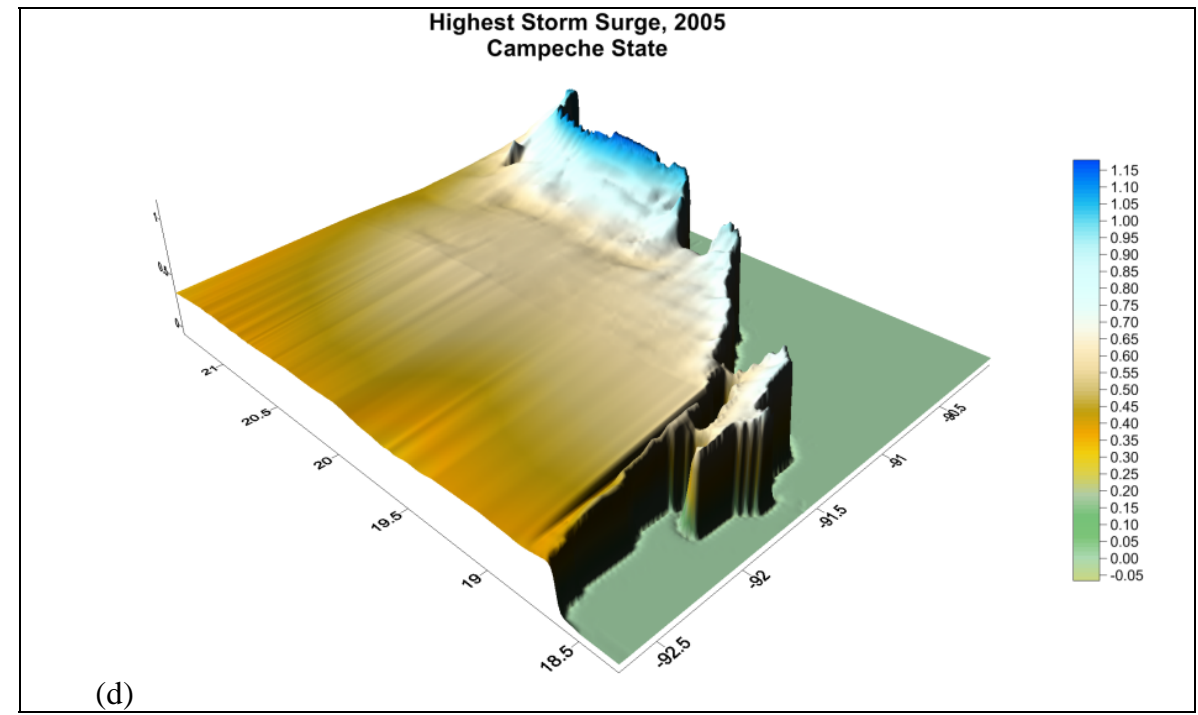

Figure 7. Storm surge levels for Campeche State, 2005

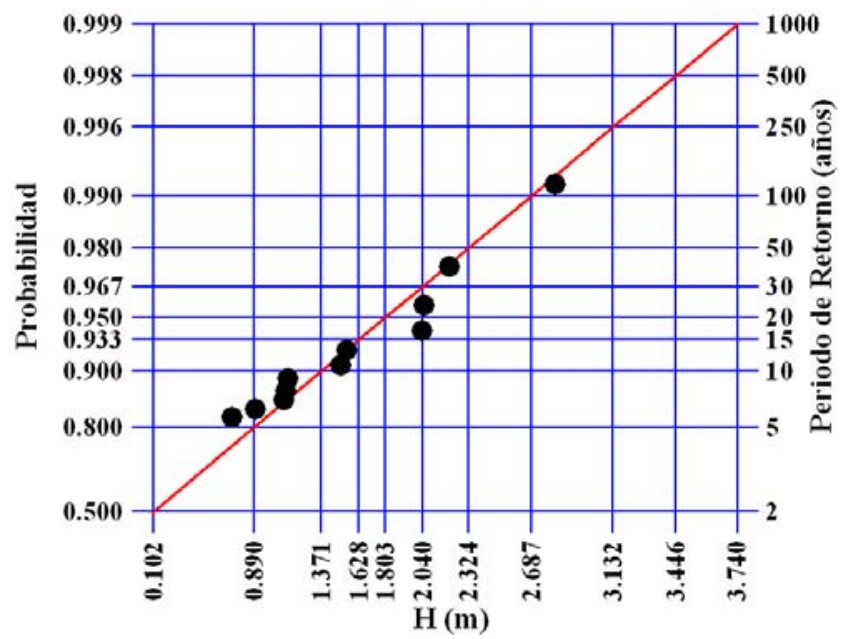

Figure 8. Storm surge levels for San Francisco de Campeche, Campeche

Figure 10, gives the storm surge levels for 10, 3050 and 100 year return periods, for the Gulf of Mexico. These results were obtained from the Weibull distribution of each cell of the numerical domain. 


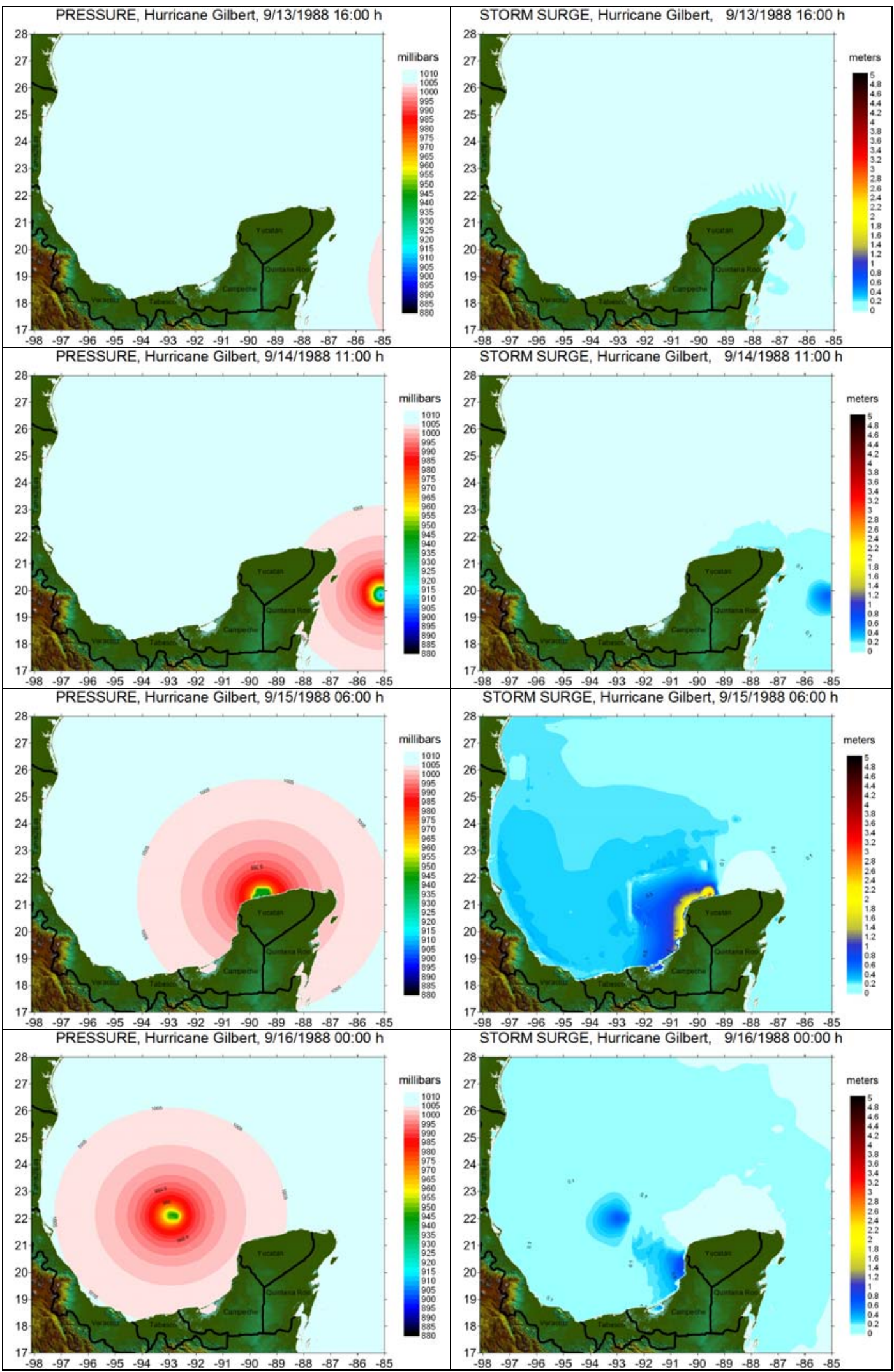




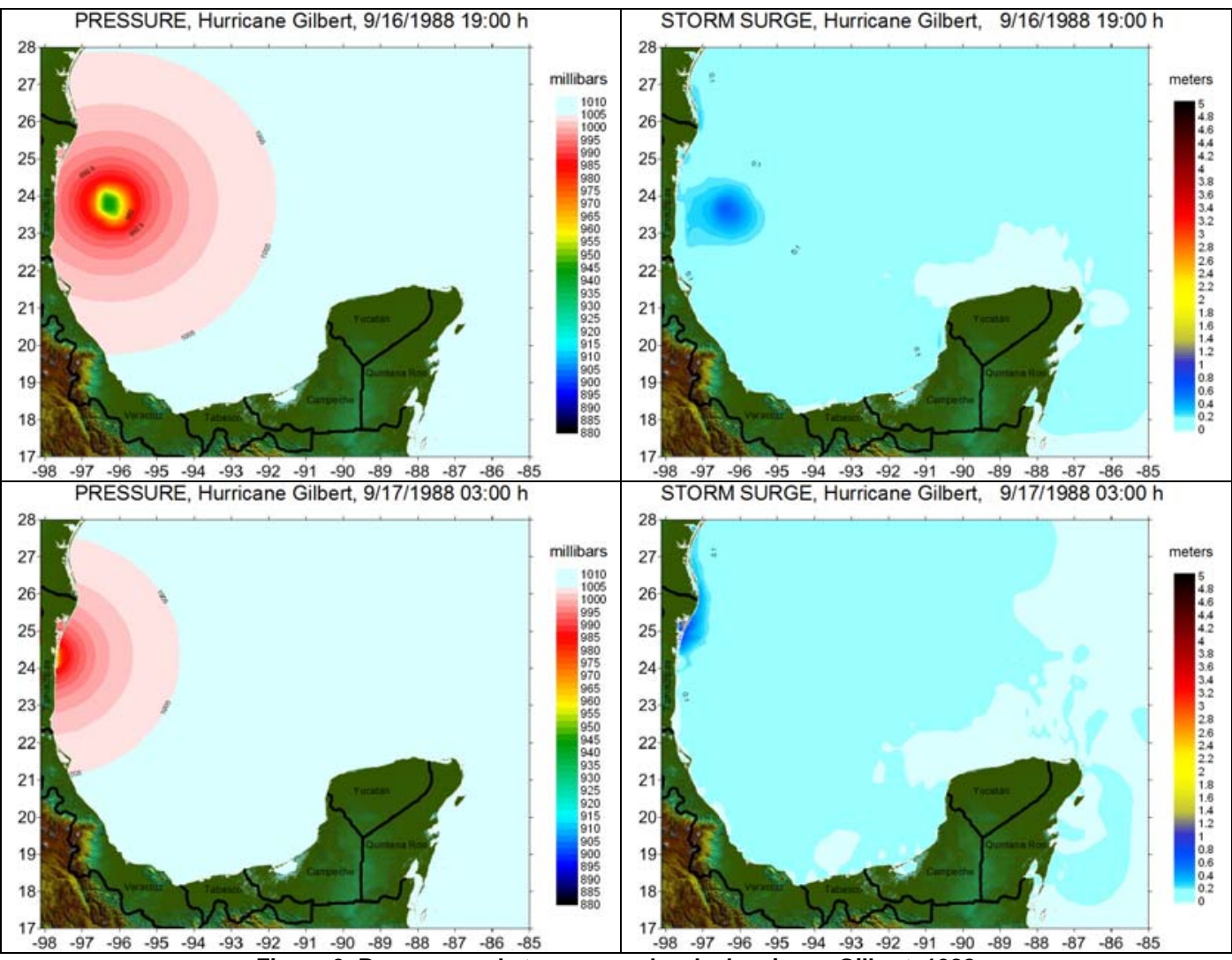

Figure 9. Pressure and storm surge levels, hurricane Gilbert, 1988

\section{Storm Surge, $\mathrm{Tr}=10$ years}
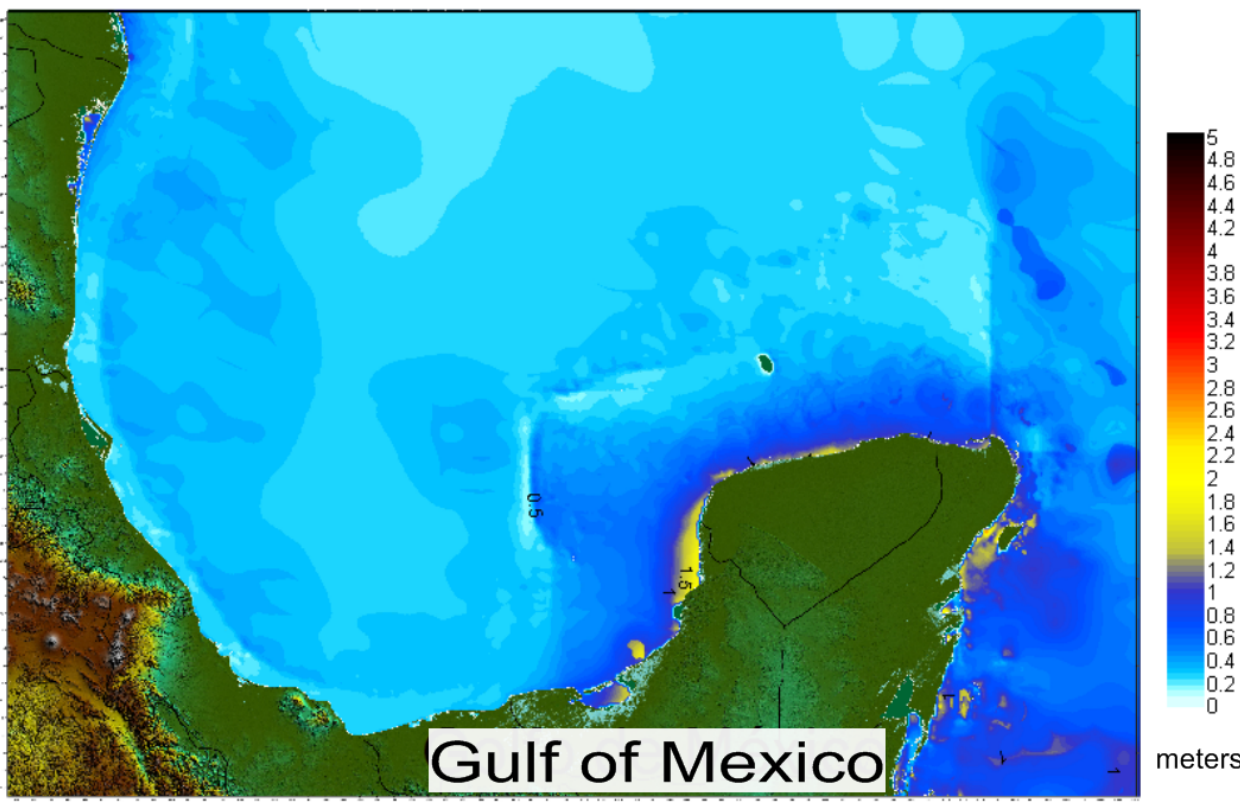


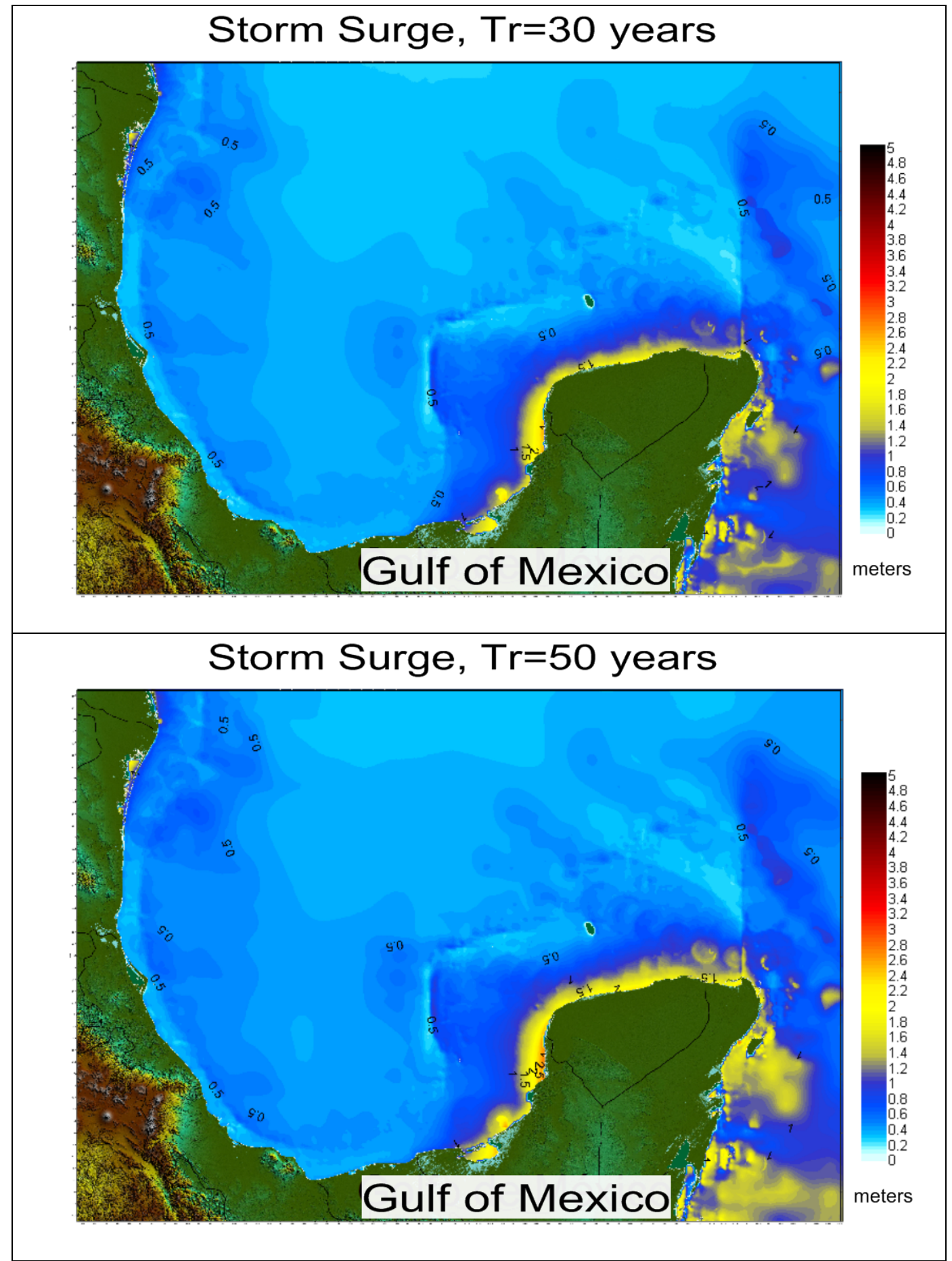




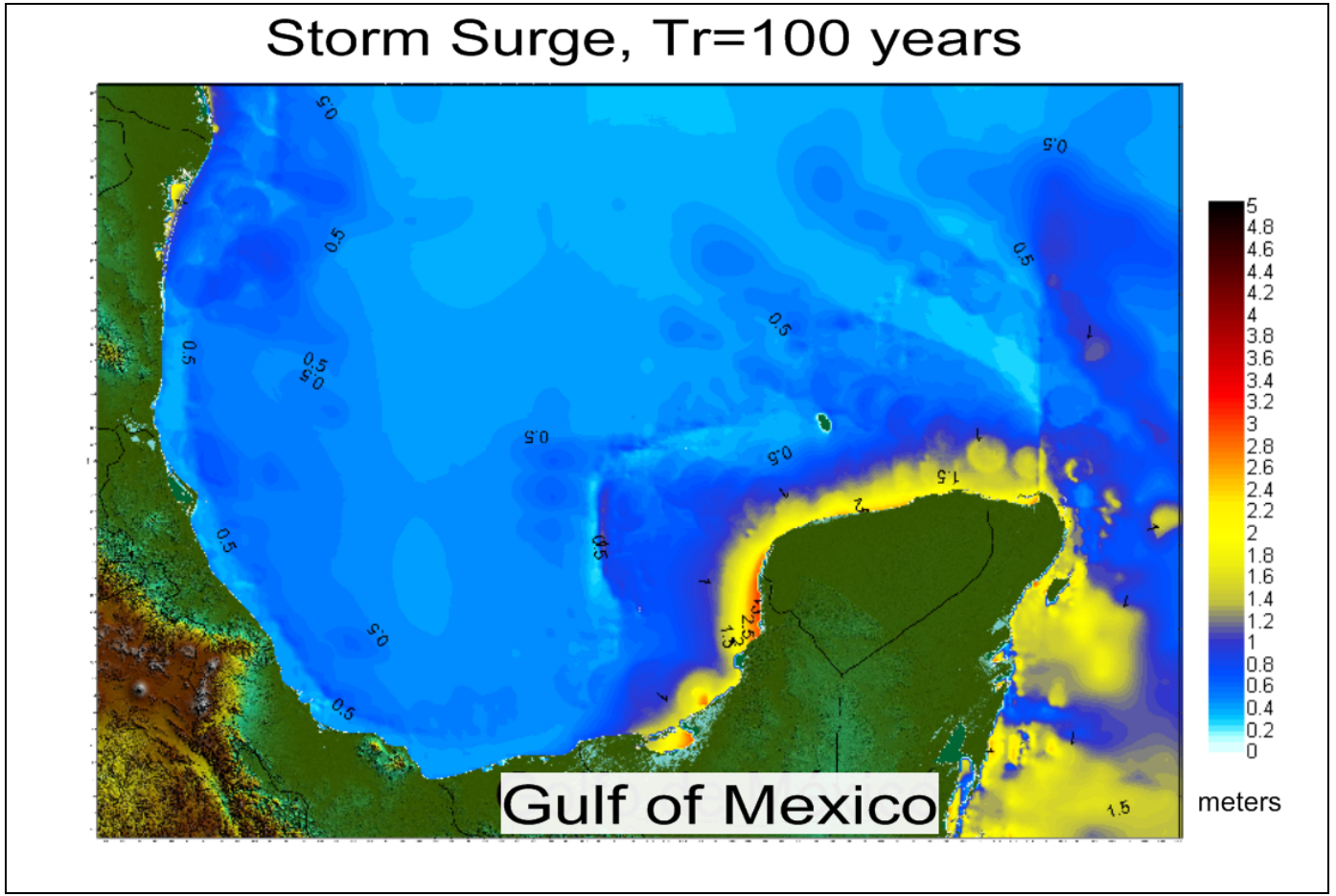

Figure 10. 10, 30, 50 and 100 years return period levels for Gulf of Mexico.

Figure 11 represent the storm surge in the north Pacific grid caused by wind with constant direction and variable magnitude from 63 to $155 \mathrm{~km} / \mathrm{h}$,

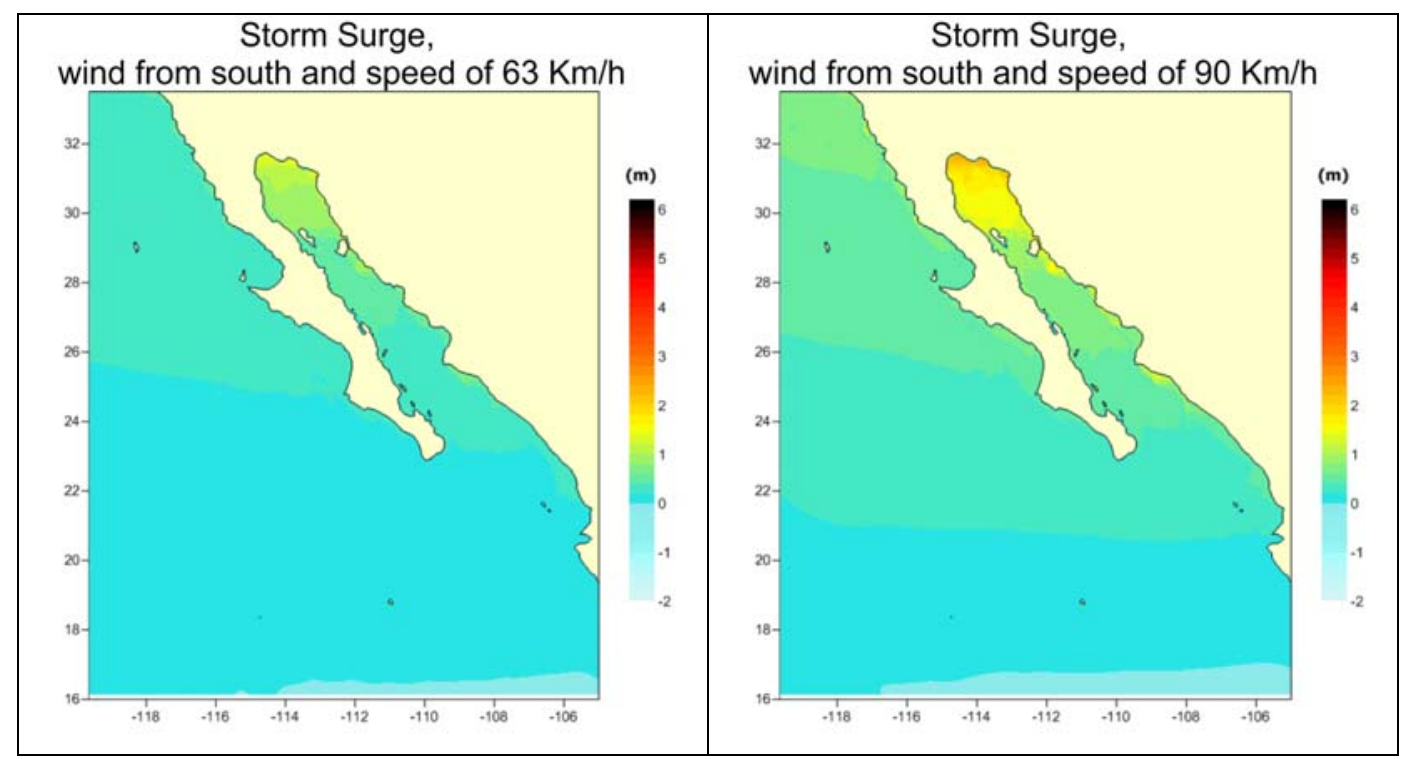




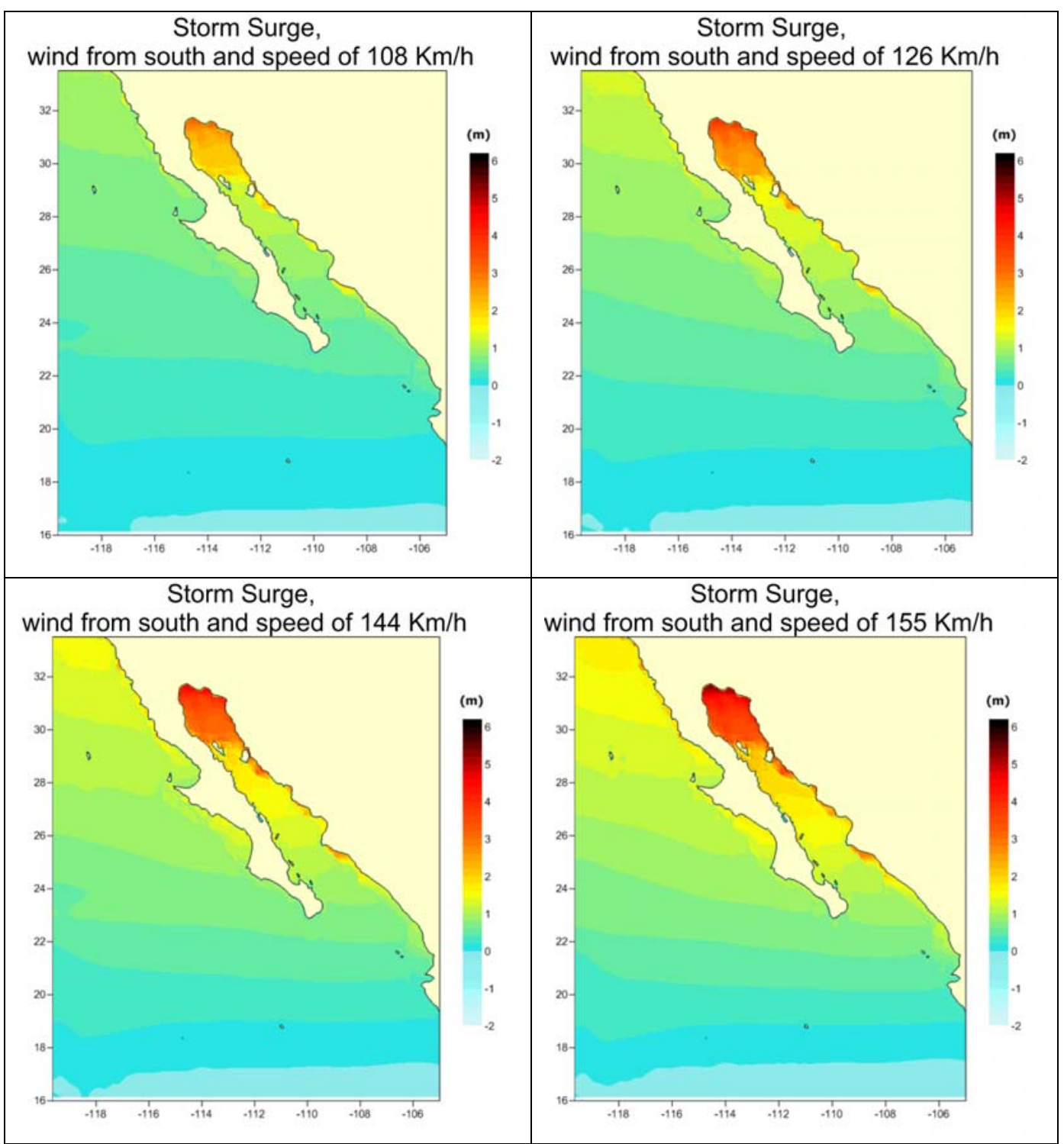

Figure 11. Storm surge for wind with constant direction and variable magnitude, North Pacific grid

\section{Geographic Information System}

All the information obtained for this work was compiled in a Geographic Information System, useful for Civil Protection Agencies and infrastructural developers in México, figure 12.

\section{CONCLUSIONS}

The methodology implemented is useful for the calculation of storm surge induced by tropical cyclones and synthetic winds. For this study almost 200 hurricanes that had impact in the last 62 years the Mexican Coasts were modeled, the highest storm surge level being $4.5 \mathrm{~m}$.

The numerical model was validated with field and qualitative information. One of permanent objectives of the authors is the annual modeling of the last hurricane season and updating of the extreme values analysis.

A Geography Information System which can be useful for Civil Protection and Coastal Management authorities was developed. 


\section{ACKNOWLEDGMENTS}

The first author wishes to acknowledge the postdoctoral scholarship given by CONACYT by means of Project CNA-2006-01-48639, "Ubicación y caracterización de zonas en peligro de inundación por marea de tormenta en las costas de México

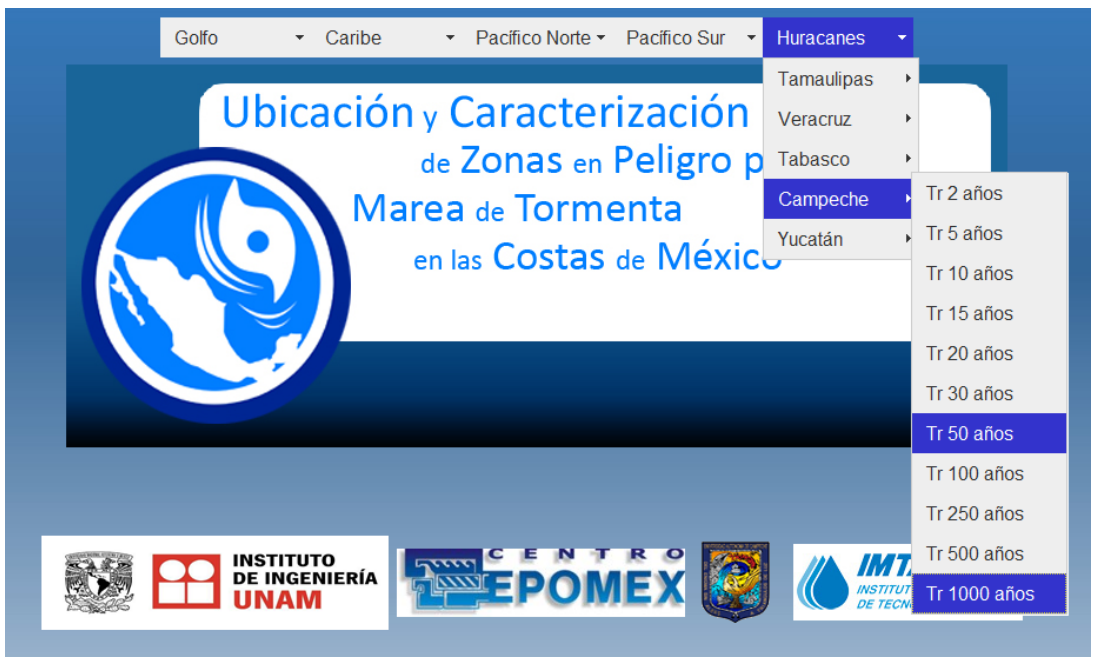

Figure 12. Geographic Information System.

\section{REFERENCES}

Bautista, G. 2005. Marea de tormenta inducida por ciclones tropicales. Tesis Doctoral, División de estudios de posgrado de la Facultad de ingeniería, Universidad Nacional Autónoma de México.

Bretschneider, C.L 1990. Tropical cyclones. Handbook of Coastal and Ocean Engineering, Gulf Publishing Co.

Castanedo, S. 2000. Desarrollo de un modelo hidrodinámico tridimensional para el estudio de la propagación de ondas largas en estuarios y zonas someras. Tesis Doctoral, Escuela técnica superior de ingenieros de caminos, canales y puertos, Universidad de Cantabria.

Falconer, R.A., 1994. An introduction to nearly-horizontal flows. Coastal, Estuarial and Harbour Engineer's Reference Book. Ed M.b. Abbott y W.A. Price, Chapman \& Hall, Londres.

Posada, G., Silva, R. \& de Brye, S. 2008. Three dimensional hydrodynamic model with multiquadtree meshes. American Journal of Environmental Sciences. 4(3): 209-222.

Posada, G., Simmonds, D., Silva, R., Pedrozo, A. 2008 A 2D Hydrodynamic Model with MultiQuadtree Mesh. Ocean Engineering Research Advances. Chapter 8, Pag 205-241, Ed. Alan I. Prescot. ISBN 978-1-60021-777-7,1-60021-777-X.

Ruiz, G., Silva, R., Posada, G., Pérez, D. \& Bautista, E. 2009. Modelo híbrido para la caracterización del oleaje. Revista Ingeniería Hidráulica en México. Vol. XXIV, número 3 pp. 5-22.

Ruiz, G., Mendoza, E., Silva, R., Posada, G., Pérez, D., Rivillas, G. Escalante, E., Ruíz, F., 2009. Caracterización del régimen de oleaje y viento de 1948-2007 en el litoral mexicano. Revista de Ingeniería del Agua Vol 16. No 1, Spain.

Silva R, Díaz G., Contreras A., Bautista G. \& Sánchez C., 2000 Determination of oceanographic risk for hurricanes on the Mexican coast, $6^{\text {th }}$ international Workshop on Wave Hindcasting and Forecasting, pg 137-160. 